\title{
THE USE OF PERIODONTAL SURGERY TO ENHANCE THE RESULTS OF RESTORATIVE DENTISTRY
}

\author{
E. BARRIE KENNEY* e WALDYR E. CARNIO **
}

\section{ABSTRACT}

Periodontal disease and dental caries share a common etiological agent namely bacteria from dental plaque. $1,2,3$ These two dental diseases frequently occur together and there is a positive correlation between the incidence of dental caries and the incidence of periodontal disease. 4,5 Therefore it is essential that caries treatment must be coordenated with periodontal therapy. During initial therapy periodontal procedures and operative procedures are often carried out together. This conjunctive approach is also applicable to the surgical component of periodontal surgery. At the time that periodontal surgery is being carried out it is important that the exact restorative treatment plan be finalized so that the surgical technics ca be modified enchance the results of these restorative procedures. Periodontal surgery can be classified into two broad categories Firstly surr.ry aimed at eliminating the effects of periodontitis e.g. periodontal flap surgery, and secondly surgery aimed at correcting aificits of gingiva e.g. mucogingival surgery. Many patients who require these surgical procedures also need to have restorative dentistry and prosthetic carried out in the same area. It is important that the periodontal surgery procedures must be coordinated with restorative dentistry and prosthetic procedures

\section{PERIODONTAL FLAP PROCEDURES}

In tnose patients where periodontal flap procedures are to be utilized to treat periodontal defects, it is imperative that the operator be aware of the final positioning of the gingival crest. In many situations the gingival tissue is apically positioned during periodontal flap procedures, and the level of the gingiva is modified further by the healing process. Clinical observations show that in general terms the gingival margin becomes stabilized after three months postperiodontal surgery. During this initial post-surgical time period, there ist at first an apical positioning of the gingiva compared to the level at which the tissues were sutured. However, by three months this tissue has moved coronally so that it is at, or within a millimeter of the level of the tissue at the completion of the surgical procedure. Understanding this phenomena is important in those patients who are to have margins of restorations placed into gingival environment following periodontal surgery. The movements of the level of the gingiva, postsurgically will vary somewhat from patient to patient, but the general guideline should be that final restorations should not be placed into the gingival crevice until three or four months postperiodontal surgery. Following this guideline not only insures that the level of the gingival margin has stabilized, but will also provide the operator with a gingival crevice which has completed its healing process and has the potential to have reorganized into a health tissue.

In patients who are to receive extensive crown and bridge work in association with periodontal surgery, it is frequently advisable to utilize provisional restorations made of self-curing acrylic resin. This will enable the dentist to ascertain of the tissues to the crown contours, margins, and occlusal patterns which will finally be utilized. These provisional restorations should be placed during initial therapy and are cemented in such a way they can be removed during periodontal flap procedures. Removal of these provisional restorations provides an enhancement of the access to the interproximal alveolar bone, and so facilitates the techniques of periodontal flap surgery. (Fig. 1) Following the healing of the surgical procedures, the patient then has the opportunity to demonstrate their ability to maintain plaque control in a situation analogous to that which will be created by the final cast restorations. Modifications of occlusal patterns, interproximal and buccal contours, and margin placement can be carried out in the provisional restorations in order to be sure that the final restorations will provide the maximum benefits to the patient.

When periodontal flap procedures are used in molar areas where crown and bridge procedures are planned, the osseous contours created surgically should be in harmony with the crown contours created in the restorations. In the region of the buccal root furcations, the osseous tissue should be grooved with an apically directed groove running from the alveolar crest. Similarly the crown contours and tooth preparation, should have an accentuated buccal groove running occlusally from the furca area. In those situations where a root resection is to the carried out, the osseous surgical technics should also be coordinated with the contours of the crown and prepared tooth, so that the final architecture of the periodontium is in harmony with the restoration (Fig. 1, Fig. 2).

In those situations where it is required to increase the crown length prior to cavity preparation, periodontal surgery

\footnotetext{
* Professor of Periodontics and Director of Postgraduate Periodontics, Los Angeles, U.S. A. School of Dentistry.

* Professor of Periodontics, Universidade Estadual de Londrina, Estado do Paraná.
} 


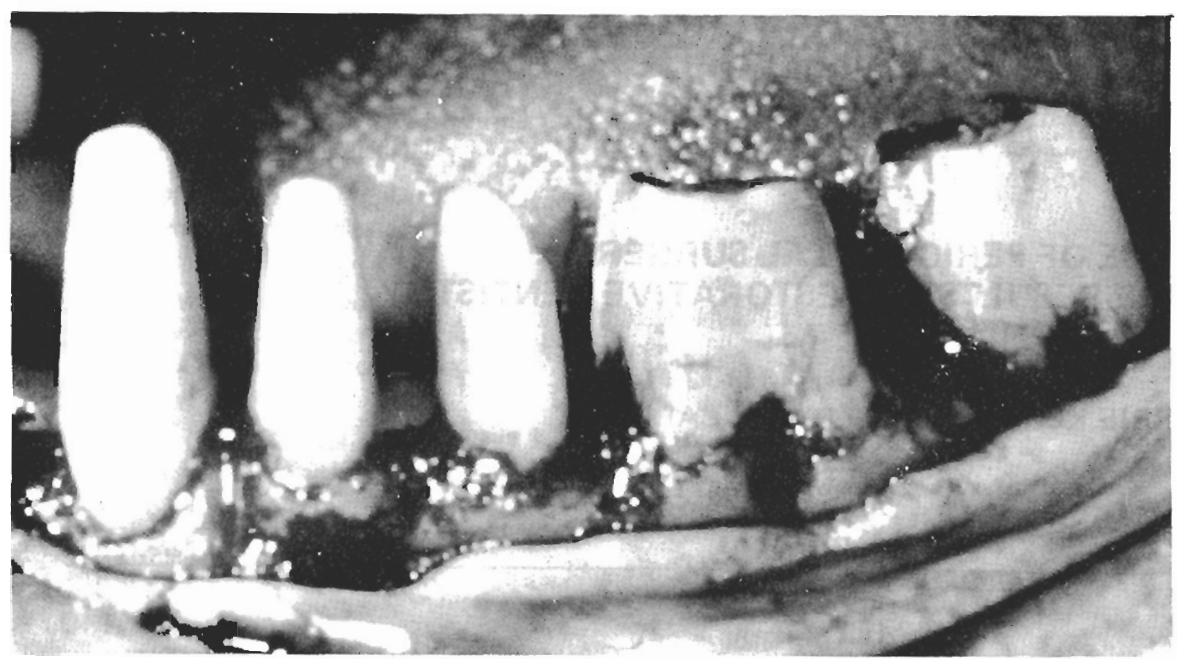

FIG. 1 - Buccal and Lingual flaps with osseous recontouring of the interdental and furcation areas in harmony with crown preparations. Removal of provisional restorations enhances surgical access.

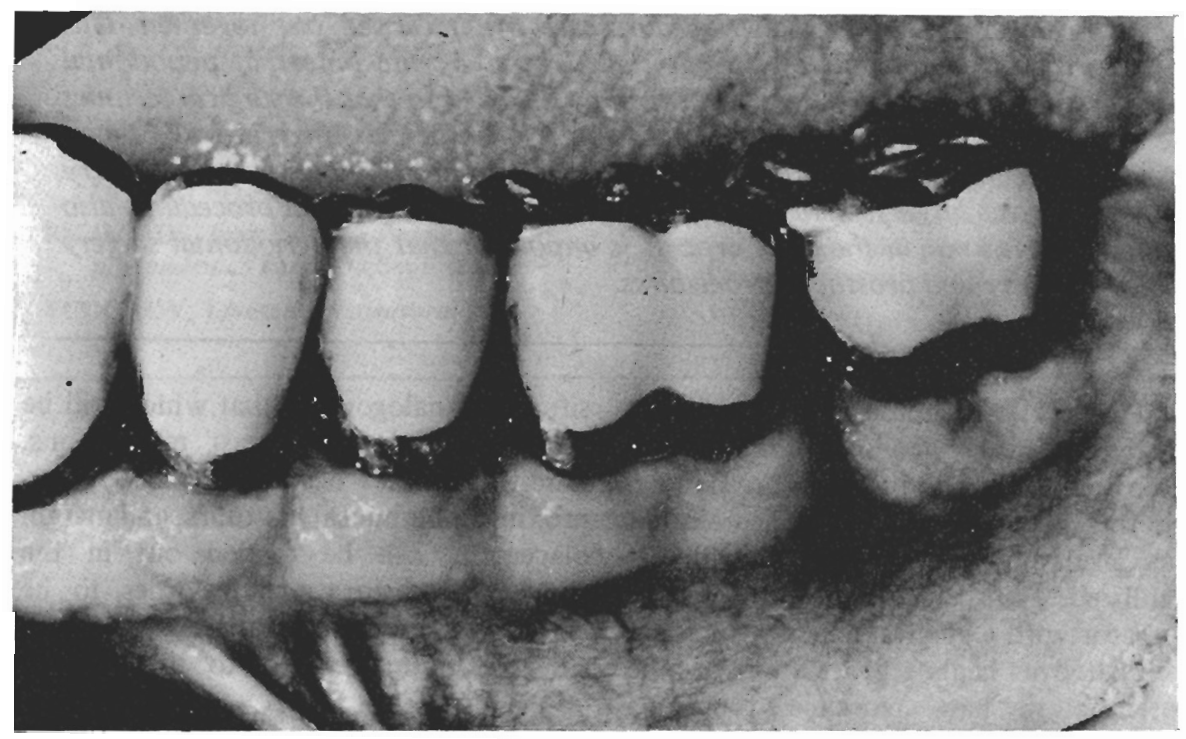

FIG. 2 - Yeriodontal and restorative therapy completed in case seen in Figure 1. Note supragingival margins, accentuated contours of midbuccal grooves and healthy gingiva.

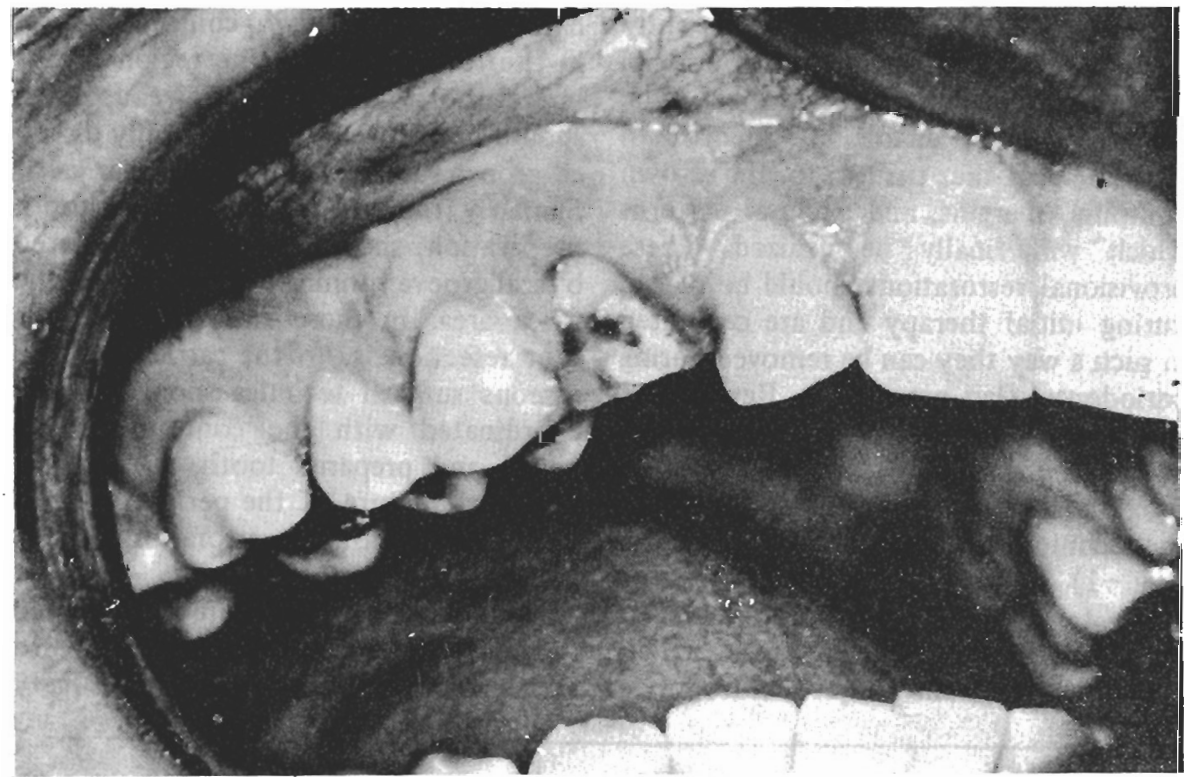

FIG. 3 - Fracture of crown on up per canine extending subgingivally to just below the alveolar crest. plays an important role. It must be stressed that in most cases it is necessary to utilize a flap procedure, as the simple removal of tissues by gingivectomy often results in the creation of a mucogingival problem because of the loss of gingival tissue. The methods utilized for crown lengthening follow the general principles of flap design that is used for conventional periodontal flap procedures. However in those areas where an edentulous area is adjacent to a crown to be lengthened, the incisions are modified so that a triangular shaped wedge of tissue is removed over the area of edentulous ridge. Flaps designed in this way ensure that the tissue remaining is thin and can be positioned in such a way that it is closely adapted to the underlying osseous structures. The size of the tissue removed in the wedge determines how much crown lengthening will occur in the interproximal area.

In those patients where crown lengthening of only the labial or lingual surfaces is required the apical positioning of flaps can used to lower the attachment level of the gingiva in an apical direction. It must be remembered that in some situations it may be necessary also to remove osseous tissue in order to reestablish the periodontal support mechanism at a more apical position. The space that occurs naturally between the most apical portion of the epithelial lining of the gingival crevice, and the alveolar bone is a millimeter to a millimeter and one half. Therefore, if a crown extention procedure is carried out, ist is necessary to first determine the level at which the gingiva is to be positioned against the tooth. Then and additional $2-3 \mathrm{~mm}$ apical to this is provided for the gingival crevice, together with an additional millimeter to a millimeter and half for the level of the alveolar crest. If after making these determinations the new level of the alveolar crest is apical to where alveolar crestal bone is presently in place, it will be necessary to remove osseous tissue and to recontour the outer surface of the alvelous in order to establish the periodontium at a more apical position (Fig. 3, Fig. 4, Fig. 5, Fíg. 6).

These techniques for increasing the lengths of the clinical crown also have application in those situations where a tooth fracture has occured. Frequently tooth fractures occur in such a way that the apical extension of the fracture is slightly below the level of the alveolar bony housing. If this tooth is to be restored, and the restoration is to be extended to the apical level of the fracture line then osseous tissue recontouring is necessary (Fig. 3, Fig. 4, Fig. 5, Fig. 6). 
In order to apically position flaps over individual teeth as described above, it is necessary to design the flaps in such a way that there are vertical releasing incisions which extend apically beyond the mucogingival junction. It is of great importance to ensure all releasing incisions are into the mucosa and extend at least $5 \mathrm{~mm}$ apical to the mucogingival junction (Fig. 5). Releasing incisions that do not have the required length do not permit apical positioning of the gingiva, as the dense collagenous tissue making up the body of the gingiva is not elastic. In contrast the alveolar mucosa has a great number of elastic fibers and once flaps have been extended into this tissue the repositioning of tissues in a apical direction is facilitated. On the palatal surface of teeth, apical positioning is achieved by ensuring that the initial incision removes the necessary amount of tissue in the marginal gingival. The problems of creating a mucogingival deficit do not apply. on the palatal tissue as the palatal tissue has the same characteristics as gingiva. Therefore, an accentuation of the scalloping seen in the gingival margin is carried out with the initial incision. This allows for a palatal flap design which will provide apical positioning of the tissue as well as adequate tissue to cover the interdental bone when the flap is sutured.

\section{MUCOGINGIVAL SURGERY SOFT TISSUE AUTOGRAFTS}

In clinical situations where a narrow band of gingiva exists, and there is to be a subgingival restoration placed into the gingival sulcus it is necessary to create an adequate width of gingiva prior to the restorative procedures. An inadequate width of gingiva predisposes the gingiva to the effects of dental plaque ${ }^{6}$. Failure to create an adequate width of gingiva will result in a compromised situation where the risks of gingival inflammation, pocket formation and gingival recession are increased by the presence of subgingival margins. Subgingival margins of restorations provide increased retention of denta1 plaque and so increase the risk of damage to gingival tissues. $7,8,9$ Also the operative procedures associated with restorative crown and bridge and prosthodontic procedures, frequently place undue trauma on the gingival tissues and can cause significant tissue damage if an inadequate width of gingiva is sresent.

The most commoniy used technique to create an adequate width of keratirized gingiva is the use of the soft tissue aurograft or free gingiva graft 10 . In order to catermine the widh of gingiva piesent,

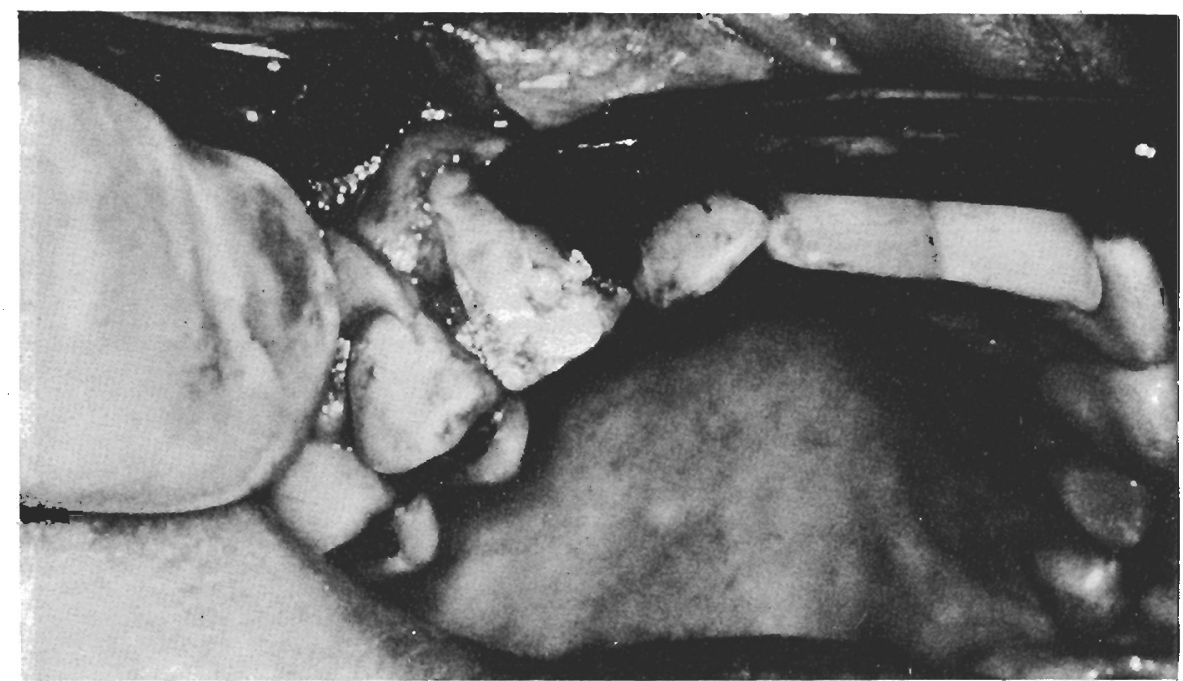

FIG. 4 - Surgical access to tooth in Figure 3. Note reduction of alveolar crest to expose fracture line.

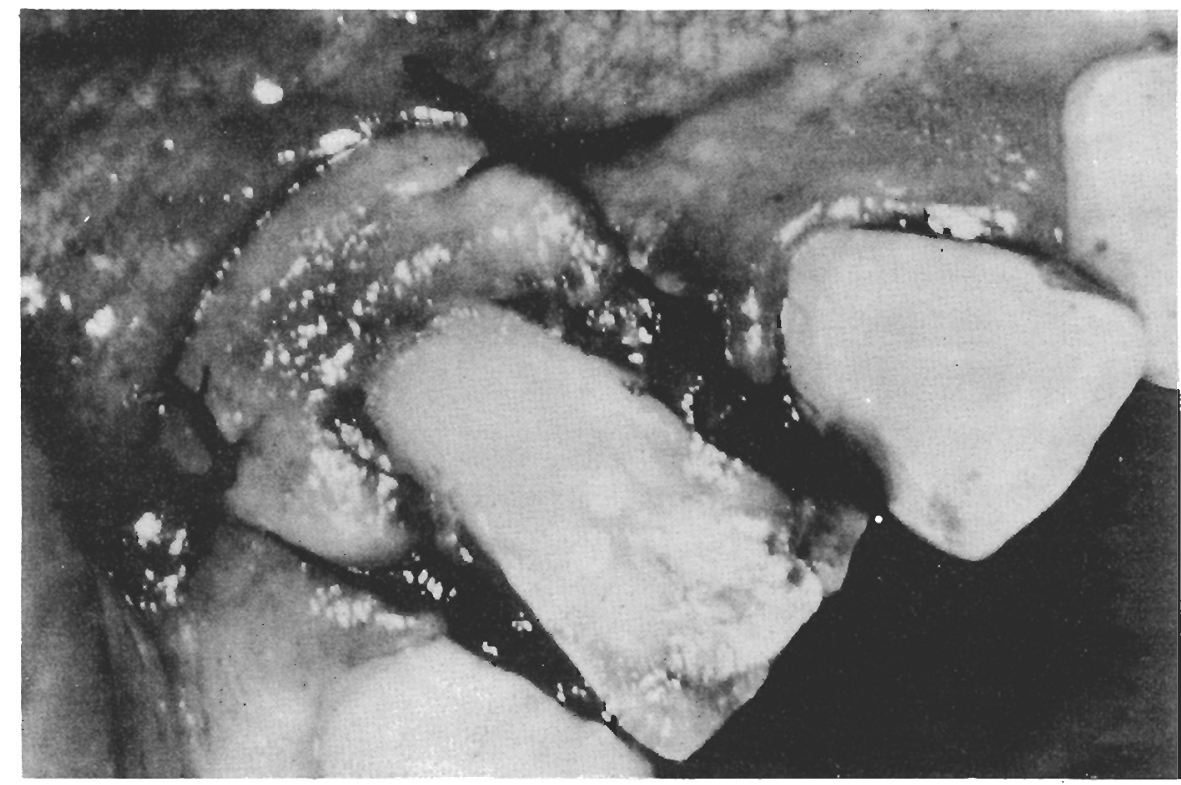

FIG. 5 - Same case as Frgures 3 and 4. Vertical incisions extended into alvouras mucusa facilitate apical positioning of labial flap.

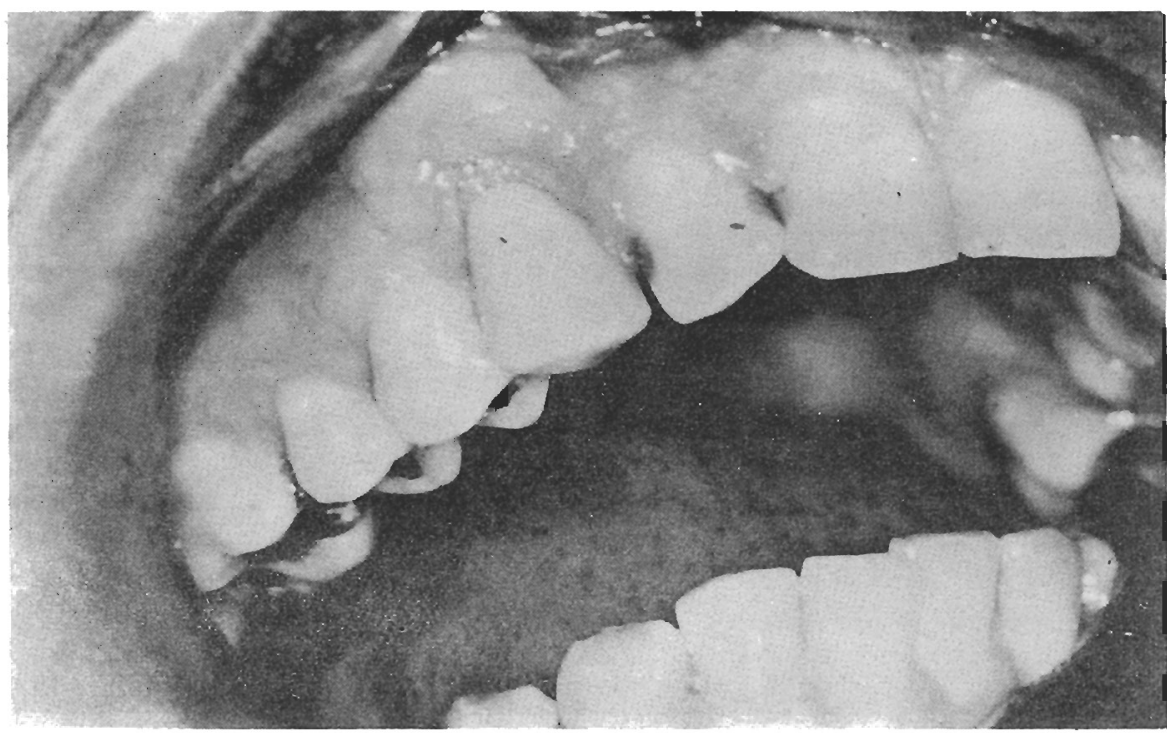

FIG. 6 - Postsurgery, postrestorative therapy of case in Figures 3 and 5. Note that and adegiate width of gingiva has been maintained by use of flap procedure for crown extension. 


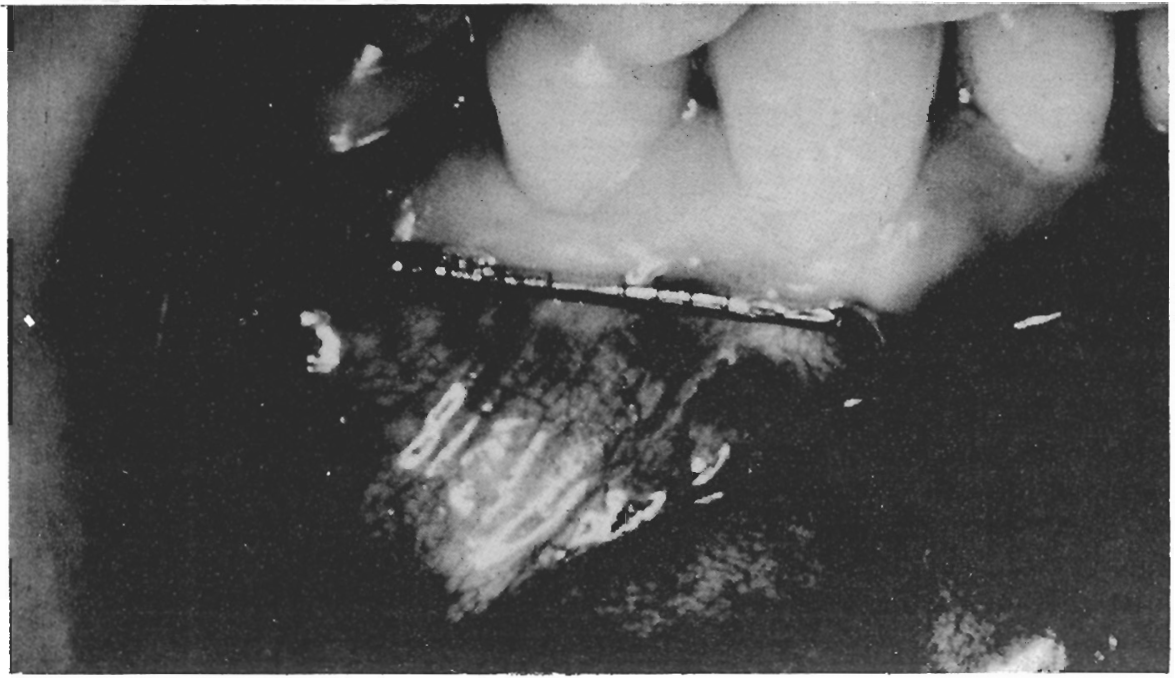

FIG. 7 - Use of priodontal probe to detect mucogingival junction. The bunching up of alveolar mucosa at the mucogingival junction.

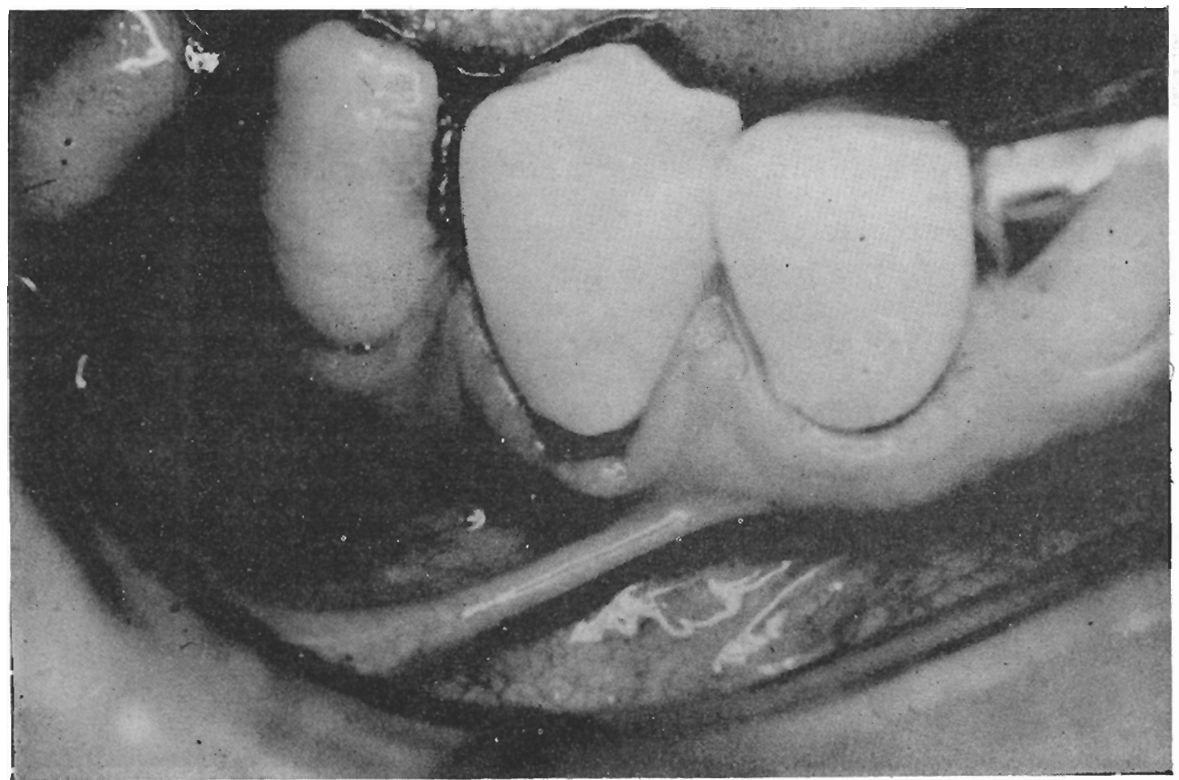

FIG. 8 - A crown has been placed into an area with excessive muscle pull and inadequate band of gingiva, resulting in gingival inflommation and rocession.

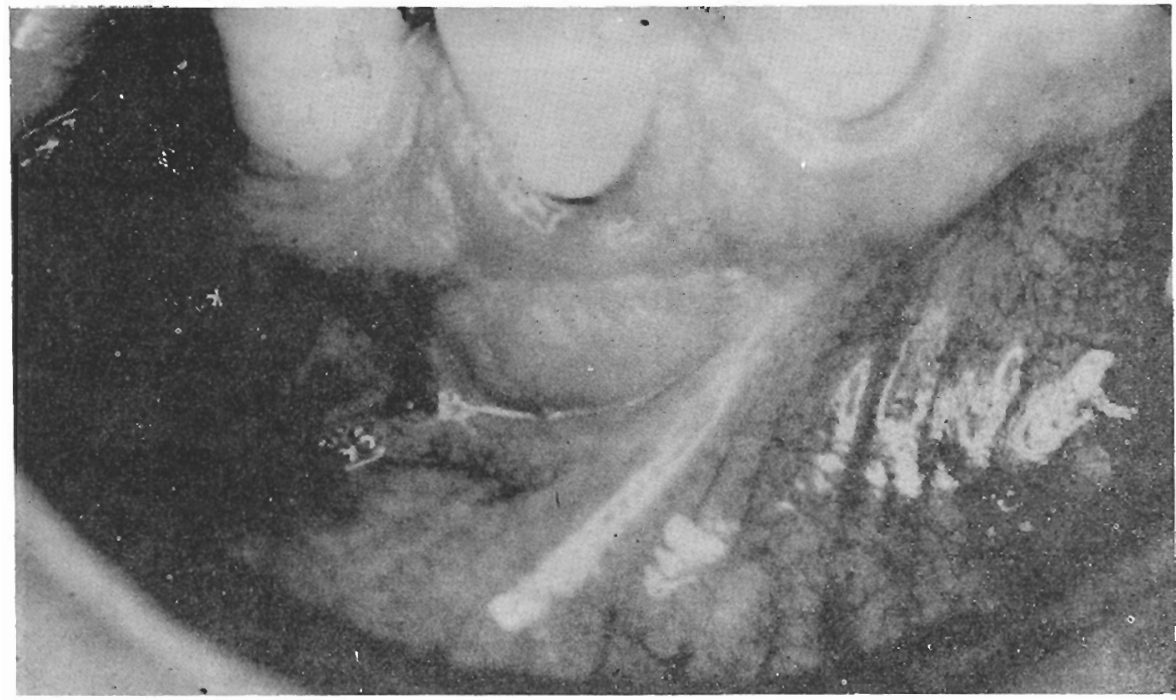

FIG. 9 - Soft tissue autograft placed in case from Figure 8. Four months postsurgical, The muscle pull on the gingiva has eliminated, and some coronal creeping of the gingival margin has occured. Note that ideally the graft should have preceeded the restoration. the mucogingival junction is furst detected, and then the amount of gingival tissue is measured by the distance from the mucogingival junction to the free gingival margin. In some clinical situations it is difficult to visually identify the mucogingival junction. This junction can be clearly identified if a periodontal probe is placed on the apical portion of the mucosa and moved coronally with the measuring portion of the probe in contact with the tissue along its whole length. Oral mucosa will roll ahead of the probe, and cause a bunching up of tissue at the mucogingival junction. Once the probe passes this junction the firm consistency of the gingiva will not permit tissue to bunch up in front of the probe (Fig. 7),

The width of the clinical gingiva is of direct importance in determining the need for a soft tissue graft. In general if this width is less than $2 \mathrm{~mm}$ there is a need to place a soft tissue autograft if a restorative dental procedure is to be carried out in the gingival crevice area (Fig. 8, Fig. 9) of equal importance to the measured width of the gingiva, is the functional abilities of this tissue. In some situations there may be pockets extending apically beyond the mucogingival junction, which will create a situation where the gingiva that is present is not attached directly to the root surface or alveolar bone. This type of mucogingival deficit of attached gingiva is best treated by flap procedures directed at pocket elimination. In those situations where there are pockets extending apically beyond the mucogingival junction, and there is also an inadequate width of clinical gingiva, it is necessary to carry out a soft tissue autograft prior to the periodontal flap procedures.

Another important test to carry off in order to ascertain the effectiveness of the width of gingiva is the tension test. In this test the buccal mucosa is pulled away from the tooth and direct visualization of the effect of this movement on the gingival margin is carried out. In areas where the gingiva is inadequate there will be a movement of the gingival margin away from the tooth, and an opening up of the gingival crevice. In cases where this occurs augmentation of the widih of gingiva is essential. In some situations the gingival margin will not be moved away from the tooth, buî blanching will occur in the entire gingival tissues. This blanching indicates a strong tendency for the muscle activities of the mucosa to pull the gingival margin away from the tooth and so induce gingival recession and inflammation. In clinical situations where 
blanching occurs and a restorative procedure is to be carried out involving the gingival crevice area, a soft tissue autograft is indicated.

Soft tissue autografts may also be utilized in order to provide an increased width of keratinized tissue and to reduce muscle pull in areas where removable partial denture bases are to be seated. Failure to recognize the need for a mucogingival procedure in these areas can lead to severe design problems, in those situations where muscles are attached in a very occlusal position to the gingiva or edentulous ridge area (Fig. 10, Fig. 11).

In most situations the tissue that is utilized for soft tissue autograft is obtained from the palatal mucosa. The palatal mucosa has an identical histological structure to that gingiva. Both tissues contain a stratified squamous epithelial covering which is keratinized and have a dense layer of connective tissue in the region immediately below the epithelial covering. Pala tal tissues obtained for grafts should be in the second premolar to second molar area. By utilizing this area and taking grafts which are no thicker then $2 \mathrm{~mm}$, the operator can avoid involving the other palatal tissues which are not valuable as substitutes for gingiva. Grafts which are taken from an area more anterior then the second premolar frequently have rugae on their surface, and this is insuitable for grafting to the gingival area. Grafts that are taken from an area close to the midline of the palate frequently contain excessive amounts of glandular tissue and increase the risk of involving the major palatine blood vessels in the surgical procedure. In all areas of the palate it is important to use an approach which allows the tissue to be taken to involve only the superficial layers of the palate. The deeper areas of the palate contain accessory salivary glands, fat tissue, blood vessels and nerves, and disruption of this tissue can carry serious consequences to the surgical procedure.

Once the graft tissue is removed from the palate it is sutured to position at the bed of tissue which has been prepared in the recipient area. Although there are reports in the literature of preparations which result in the graft being placed directly onto alveolar bone, it is more advisable to place the graft onto a bed of periosteum. The bed preparation should be such that there are no tags of granulation tissue remaining on the surface of the periosteum, so that the gnaft can be firrty bound down during the healing process to the thin layer of periosteum covering the alveolis bone. Both the donit area and the recir in si:a area

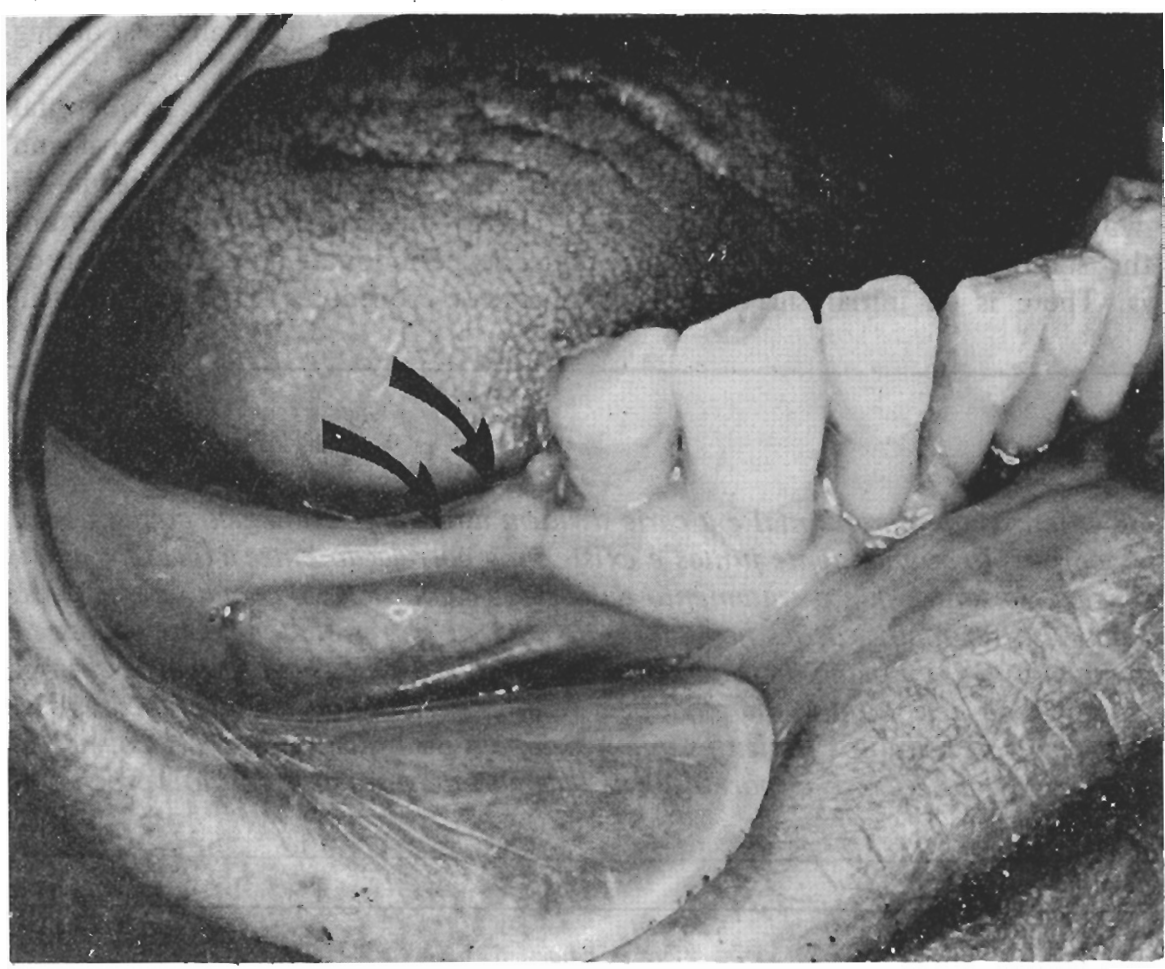

FIG. 10 - High muscle attachment to edentulous region (arrow) means that saddle area of partial denture cannot be designed in appropriate manner.

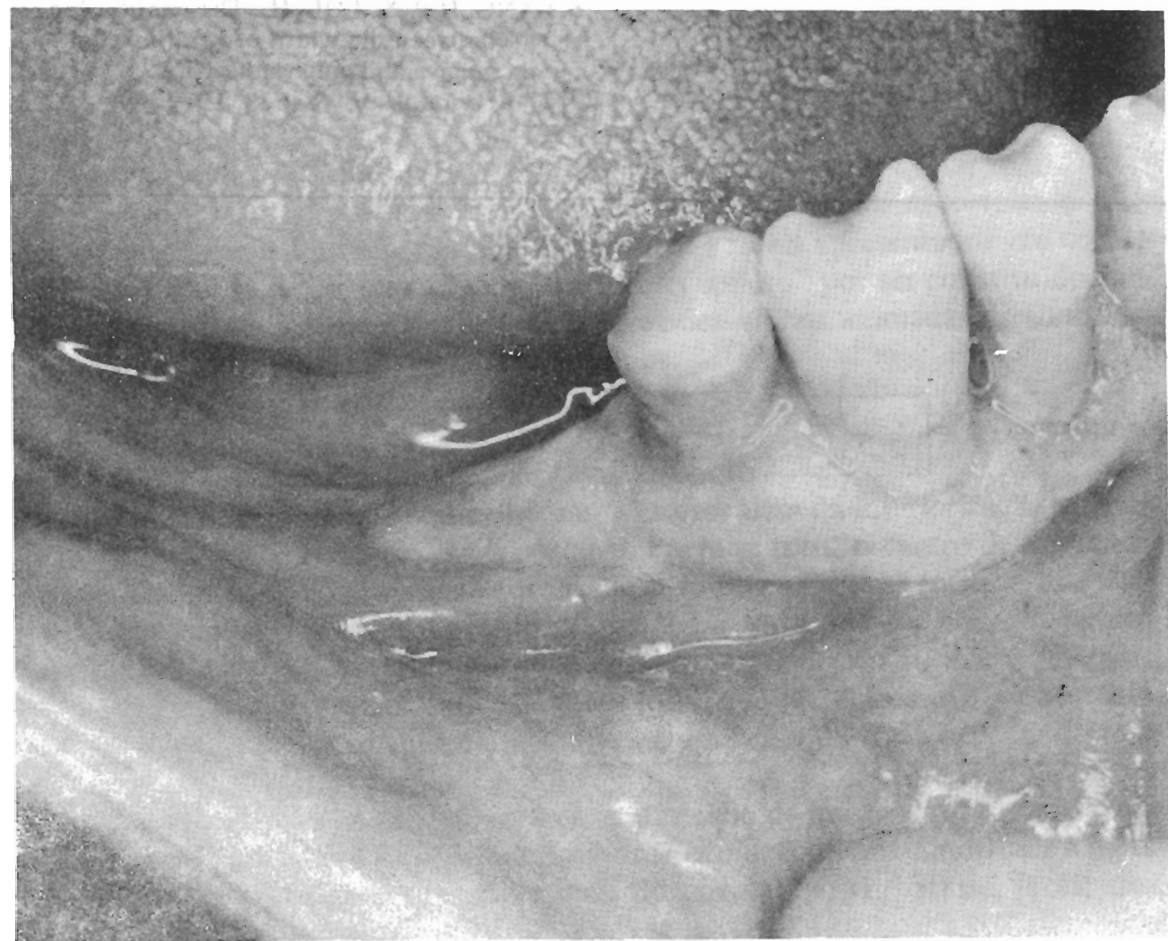

FIG. 11 - Soft tissue autograft placed in case seen in Fig. 10. Nore apical positioning of muscle, cnd keratinized tissue covering anterior portion of saddle area. 
covered with periodontal dressing for 7 to 10 days to protect these tissues during the healing processes. A period of at lease 2 months should be allowed following these procedures before operative restorative techniques area carried out. This will allow maturation of the graft and the stabilization of the amount of gingiva. There is an initial shrinkage of graft tissue, and up to $30 \%$ of the width of the gingival graft it usually lost during the healing process.

The coordination of periodontal surgery procedures with restorative and prosthetic dentistry improves the dental service to our patients. It is important that the periodontal procedures precede restorative procedures. This will result in a gingival environment which is healthy, stable and able to withstand the tissue damage associated with impression taking, cavity preparation and cementation of restorations. The use of flap procedures for crown extension and soft tissue autografts for augmentation of gingiva are essential technics for successf ul restorative dentistry.

\section{RESUMO}

A enfermidade periodontal e a cárie dividem um agente etiológico comum - as bactérias da placa dental. Essas enfermidades ocorrem frequentemente juntas e existe uma correlação entre a incidência da cárie dental e a enfermidade periodontal $\vec{E}$ essencial, portanto, que o tratamento da cárie seja coordenado com a terapia periodontal. E, para que uma cirurgia periodontal possa sofrer modificaçōes no sentido de ampliar os resultados positivos desse procedimento, deve-se organizar, no inicio de uma cinurgia, um plano de tratamento restaurador. Há duas categorias de cirurgia periodontal: a que se realiza para eliminar os defeitos da periodontite marginal pelo retalho periodontal e a que visa a corrigir os defeitos da gengiva, através de cirurgia muco-gengival E muitos pacientes que necessitam de tratamento cirúrgico, necessitam também de procedimentos protéticos em determinadas áreas. $\bar{E}$ importanie que haja coordenaçāo entre os dois procedimentos.

\section{REFERENCES}

1. GIBBONS, R.J.; BERMAN, K.; KNOETHNER, P.; KAPSIM ALIS, B. Dental caries and alveolar bone loss in gnotobiotic rats infected with capsule forming streptococci of human origin. Arch. Oral. Biol., 11:549, 1966.

2. ARNO, A; WAERHAUG, J.; LOVDAL, A; SCHEI, $O$. Incidence of gingivitis as related to sex, occupation, tobacco consumption, toothbrushing and age. Oral. Surg., 1: 587, 1958.

3. GIBBONS, RJ. \& BANGHART, S. Induction of dental caries in gnotobiotic rats with levan forming streptococous and a streptococcus isolated from subacute bacterial endocarditis. Arch. Oral. Biol., 13: 297, 1968.

4. MASSLER, M. \& SAVARA, B.J. Relation of gingivitis to dental caries and malocclusion in children 14 to 17 years of age. J. Periodontol, 22: 87, 1951.

5. RUSSEL, A.L. \& AYERS, P. Periodontal disease and socioeconomic status in Birmingham. Ala. Am. J. Pub. Health, 50: 206, 1960.

6. LANG, H.P. \& LOE, H. The relationship between the width of keratinized gingiva and gingival health. $J$. Periodontol, 44: 623, 1972.
7. BJORN, AL.; BJORN, H.; GRKOVIC, B. Marginal fit of restorations and its relation to periodontal bone levels: part II - crowns. Odont. Revy, 3: 337, 1970.

8. KARLSEN, K Gingival reactions to dental restorations. Acta Odont. Scand., 28: 893, 1970.

9. V ALDERH AUG, J. Prepareringssrensens Beliggenket Krone - Bro Synspunkter. Nor Tannlaeg Tids., 82: 386, 1972.

10. LANGE, D.E. \& BERNIMOULIN, J.P. Exfoliative cytogical studies in evaluation of free gingival graft healing. J. Clin. Pericdontol, 1: 89, 1974. 